THE TONGA EARTHQUAKE OF 23 JUNE, 1977

\title{
SOME INITIAL OBSERVATIONS
}

\author{
M. D. Campbell*, G. R. McKay*, R. L. Williams**
}

\begin{abstract}
Following the 23 June, 1977 Tonga earthquake, the authors were made available by the New Zealand Ministry of Works and Development (through the Ministry of Foreign Affairs Bi-lateral Aid Frogramme) to the Tongan Government to help survey building damage and to recommend repairs and strengthening necessary to protect the structures from future earthquakes. The authors were also required to supervise government reconstruction teams.
\end{abstract}

Recommendations are at present being prepared for structural design requirements for future building work in the Kingdom.

\section{INTRODUCTION}

The main shock of the earthquake of 22 June, 1977 caused damage on the islands of 'Eua and Tongatapu in the Tongan Group. The preliminary epicentre as issued by the United States Geological Survey is:

Time:

$$
12.0828 .3 \text { on } 22 \text { June, } 1977
$$
Universal Time. $(1.08 \mathrm{a} . \mathrm{m}$. on 23 June, 1977 local time.)

Magnitude: Richter 7.2

Location: 23.19S $175.92 \mathrm{~W}$

Depth: $\quad 33 \mathrm{~km}$.

This places the epicentre approximately $240 \mathrm{~km} \mathrm{SSW}$ of the main islands (Fig. 1).

Tonga lies in the circum-pacific belt and is no stranger to earthquakes, but events of the intensity of the 23 June, 1977 shock have not been felt for 30 years. According to Gutenberg and Richter (1) shallow earthquakes of magnitude 7 or more occurred within the same epicentral distance of Tongatapu in 1913, 1917, 1943 and 1948 together with some 25 shallow events greater than magnitude 6.0 and 10 intermediate and 4 deep events greater than magnitude 7.0 (Fig. 1). Figure 1 also includes earthquakes for the region listed by J. P. Rothé(2).

The main shock, which some reports described as heavy east west motion followed by a "churning motion together with a strong vertical component", was reputedly felt for up to 3 minutes. There were numerous aftershocks of a much lower intensity with a few still being felt weeks after the main shock. The felt intensity was assessed at MM VI and VII on Tongatapu, VII and VIII on 'Eua, and less than MM $V$ on the northern islands of Ha'apai and Vava'u. There is no obvious geological reason for the difference in felt intensity between the main islands of Tongatapu and 'Eua which are equidistant from the preliminary epicentre, fig. 1 (pers. comm. B. R. Paterson, N.Z. Geol. Survey,

* Ministry of Works and Development, Head Office, Wellington.

** Ministry of Works and Development, Hamilton.
Christchurch). The generally low standard of construction, weak materials and the absence of earthquake resistant design contributed to the extent of the damage and it was surprising that no life was lost and that there were few serious injuries. Had the earthquake occurred during the day the damage to the building housing the Prime Minister's offices and to the primary schools would have almost certainly caused loss of life.

It was apparent that the ground shaking was not exceptionally severe as statues in the Royal cemetery shifted but were not toppled and numerous buildings on long piles (precast or in-situ concrete supports above the ground for domestic dwellings fig. 2) and underground services were undamaged except in the area of the mud flats. There was no reported slipping of natural slopes but permanent ground movement occurred on filled ground, notably at Vuna Wharf, Queen Salote Wharf and around the lagoon. The fairly extensive structural damage must therefore be attributed to lack of any building codes, standards or permit requirements.

\section{GENERAL OBEERVATIONS}

\section{Horizontal Motion}

During the strong phase the horizontal motion appears to have been relatively harmonic with no single dominant pulse, e.g. there was no movement of statues or headstone in one direction. Nor were distinct directional failures observed in the standard school buildings which are widely distributed throughout the islands.

\section{Differential Movements}

Buildings without bond beams, and particularly those made of solid coral block with little mortar e.g. Prime Minister's building, Fig. 3, and St. John's College chapel exhibited severe vertical cracking as the various parts moved in different directions. Towers on churches moving out of phase with the main building generally caused separation, with some cracking up to $75 \mathrm{~mm}$ wide or failure of the tower, fig. 25, 
and/or collapse of the end walls, figs. 23 and 24.

\section{Hammering}

Where portions of structures were not adequately separated, some hammering was apparent. Evidence of this could be seen at the Tonga High School between the tower and main block and to a lesser extent between the main block and the library. The use of a hardboard as a gap filler rendered the separation seismically ineffective. Despite provision of a $40 \mathrm{~mm}$ gap. hammering between the main part of the Dateline Hotel and the adjacent bedroom block was also apparent due to the lack of stiffness of the main block (ground floor frame with very flexible columns in that direction).

\section{Liquefaction, Filled Ground}

No sand boils were observed. Lateral movement of filled ground, however, was quite marked. Construction on poorly consolidated fill is obviously likely to be damaged however well it is designed or constructed.

\section{Settlement of Buildings}

The most marked evidence of failure due to settlement occurred at the new three storey Government Administration Block. The foundation settled into the coral sand from 75 to $150 \mathrm{~mm}$ causing both the ground floor slab and the terrace slab to arch up as much as $100 \mathrm{~mm}$, i.e. the slab was dragged down by the foundations. Settlement was also apparent on several other structures on soft ground, e.g. the classroom floors at St. John's College and Beulah College dropped up to $50 \mathrm{~mm}$ relative to the outside walls. The underlying fill in these cases may have previously settled away from the slab with the earthquake dropping the floor back onto the fill.

\section{BUILDING STRUCTURES}

These are predominantly single storey. Apart from Nuku'alofa where there are several two and few three storey buildings the only substantial structures are churches. Churches are found in almost every other block in all villages and in many cases have walls up to 6 metres high and towers approaching 15 metres in height. Horizontal seismic loads do not appear to be considered in their design and there is only nominal tying down of trusses. Damage to two churches is illustrated in figures 23,24 and 25 .

\section{HOUSING}

Approximately half the houses are conventional weatherboard timber dwellings with the remainder being either traditional fales (see Fig. 15) or of concrete masonry block. Timber houses suffered little damage except for a few that fell off their "piles" (short timber or pre-cast concrete piers), figs. 4, 5. Timber is mainly imported and must be treated to resist decay and insect attack. Fales are framed from saplings and covered with coconut palms and, not unexpectedly, suffered little damage.

There has been an increasing trend towards the use of "concrete block" houses, costing about $\$ 3,000$ each, as these have advantages with regard to thermal insulation, hygiene and permanence, and they constitute at present roughly 10-15 percent of new house construction. Since most Tongans earn less than $\$ 3$ per day in Tonga (and they could only obtain the necessary capital to build these houses by working overseas, usually New Zealand) to re-build or even repair a house like this, is obviously beyond their means. Blockwork houses are usually partially reinforced with a concrete bond beam and vertical bars at wall intersections and sometimes openings, fig. 19. This form of construction was apparently adopted from New Zealand practice but the reinforcement is often inadequate and laps and grouting are particularly poor. Nevertheless the provision of even this minimal reinforcement undoubtedly saved many buildings from total collapse. On 'Eua (population 6,000 ) there were approximately 90 concrete block houses; 30 collapsed or were abandoned as unsafe (figs. $6,7,8$ ): 30 were damaged, some badly, but are still occupied, and 30 apparently undamaged. Very little repair work was being carried out as the owners, in the absence of an insurance scheme comparable to that of the New Zealand Earthquake and War Damage Commision, could not afford to do so.

\section{Reinforced Concrete Frame Buildings}

There were very few reinforced concrete frame buildings which did not include at least a few block walls. However, one building without blockwalls, the Tailulu College used by 650 pupils, was damaged and left in a seriously weakened condition. This building is a two-way reinforced concrete frame eight bays by four bays each of $4.25 \mathrm{~m}$, being two storeys high with provision for a third storey (fig. 9). All ground floor columns showed severe cracking or spalling at the top and bottom of the windows (figs. 10, 11) and the structure was close to collapse during the earthquake. The failure mode of the $300 \times 300 \mathrm{~mm}$ columns was flexural due to the very light and poorly placed steel (fig. 12). The extent of movement was particularly apparent at the stairs which were extensively damaged where they joined the slabs but in this instance the diagonal bracing effect of these stairs was fortuitous and may well have saved the building. The recommended minimum strengthening provides for two infill concrete shear panels on each face of the building. In several other buildings the presence of non structural unreinforced blockwork or other rigid elements caused cracking away from the ends of the column (fig. li) - a type of damage easily predicted by theoretical considerations, i.e. attracting seismic shears due to increase in frame stiffness and altered behaviour of the column itself. Examples of this cracking were also found at the Viola Hospital, the new Government Administration Building and a new classroom block at Queen Salote College. In a stronger earthquake this effect could. have led to serious failures.

\section{"Shear Wall" Buildings}

In many of these buildings, designed as frames, unreinforced or lightly reinforced walls acted as shear panels (fig. 13). A 
number of these were undamaged indicating that they remained essentially elastic and this considering their weak construction confirmed that the earthquake was not intense. Where the walls were more highly stressed severe $X$ cracking occurred. The main block of the Dateline Hotel exhibited this type of cracking in the masonry infill walls at ground level (fig. 14). It was also significant that in this case the cracking continued right through the column. Simple theoretical considerations indicate that virtually the whole seismic shear of the building was attracted to the columns at the ends of the infill walls (fig. 14). In many instances infill walls were not tied to the surrounding columns and beams. This was particularly so where the infill. was constructed after the frame and many walls fell out or were left so weak that they could be swayed by hand.

\section{Some General Comment on Masonry Construction}

In recent years hollow blockwork has become very popular in Tonga, but the blocks are generally extremely weak, often only about $5 \mathrm{MPa}$. The use of knock-in, bond beam or other special blocks is virtually unknown. Blocks are usually 18 " $\mathrm{x} 8$ " $\mathrm{x} 6$ " exclusive of mortar joint width but are also 4" and 9" thick. Mortar is variable in quality and tends to lack cohesion. Grout is usually mortar and placed as such. Consequently it is poorly compacted and fails to bond to the reinforcement (figs. 15, 16). Reinforcement is frequently poorly placed or missing altogether. Laps are often only a few inches long. The use of plain reinforcement instead of deformed compounds the poor bond characteristics of the grout (fig. 15). Joint reinforcement of the "blocklok" type is used on many govermnent jobs and while it could not be considered to be reinforcement in the generally accepted sense of the word it appeared to have effectively acted as "basketing" and improved the performance and generally kept the walls intact. Walls of decorative screen-blocks using "blocklok" only suffered minor damage. In view of the poor construction procedures and materials for blockwork it has been recommended that except for work that is closely supervised reinforcing should not be placed in the cells of blocks but instead only in insitu structural elements, e.g. small columns, pilasters, beams, etc. and that where possible these elements be poured after and against the blockwork (see differences between figs. 6 and 7 ).

\section{Non-structural Elements}

Once again an earthquake has shown the hazards created by not adequately supporting the top of masonry walls by dropping gable walls, figs. 15 and 17 , and unreinforced partitions, fig. 18. Damage to stairs in relatively flexible storeys was also prevelent as no allowances had been made for interstorey drift (figs. 20 and 21).

\section{CIVIL ENGINEERING STRUCTURES}

The water supply dam on 'Eua was undamaged and the bridge on 'Eua had minor damage to the holding down bolts. A section of the Vuna wharf concrete deck, which collapsed, was fairly heavily loaded at the time and with the reinforcement in a severely corroded state. Both wharves are perched on the edge of the reef and movement of the coral itself may have been a contributing factor. Slumping and spreading of the fill and overturning of rock retaining walls was particularly severe on the Vuna Wharf mole (fig. 22). There were few other civil structures on the islands.

\section{CONCLUSIONS}

While in its present state of economic development the Kingdom obviously cannot afford in general a level of earthquake resistant construction comparable to that in countries such as New Zealand, Japan or U.S.A., it also cannot risk a recurrence or even worse disruption of its infra structure as caused by the recent earthquake.

Earthquakes of intensity comparable to that of June 1977 must be expected to have recurrence periods of perhaps 20 to 30 years and under less fortuitous circumstances heavy loss of life might result in addition to the economy disruption. Lack of confidence in the safety of Tongan buildings might even be detrimental to its developing tourist industry.

In our opinion, significant improvements to the seismic resistance of many structural forms common to Tonga can be achieved with comparative ease and at little expense. But no amount of money will be effective unless the public and building industry are educated in the basic principles that lead to effective earthquake resistant structures.

Not only is there a need for effectively enforced bylaws and construction standards on codes of practice but, and this is equally important, there is a need for education of tradesmen in building construction and housing through a technical institute and by training within government departments.

Preliminary recommendations have been made to the Tongan Government with respect to minimum seismic standards that should be applied to all major buildings particularly those of two storeys or more supported by typical details for reinforced hollow masonry construction. Some recommendations have also been made with regard to low cost housing in reinforced hollow masonry.

Better earthquake resistant construction in the case of heavier buildings and building components will automatically ensure better performance in hurricanes.

In most other countries in seismic regions the effect of a destructive earthquake was required to alter established construction practices and to jolt public and administration into action with regard to code changes. Hopefully the 23 June shock will do the same for Tonga. To this effect an earthquake that causes no loss of life is perhaps a fortunate event.

\section{REFERENCES}

1. B. Gutenburg and C. F. Richter. "Seismicity of the Earth and Associated Phenomena", Princeton University Press, 1949.

2. J.P. Rothé, "Seismicity of the Earth 1953-1965". UNESCO 1969.

Paper received 24 November, 1977. 


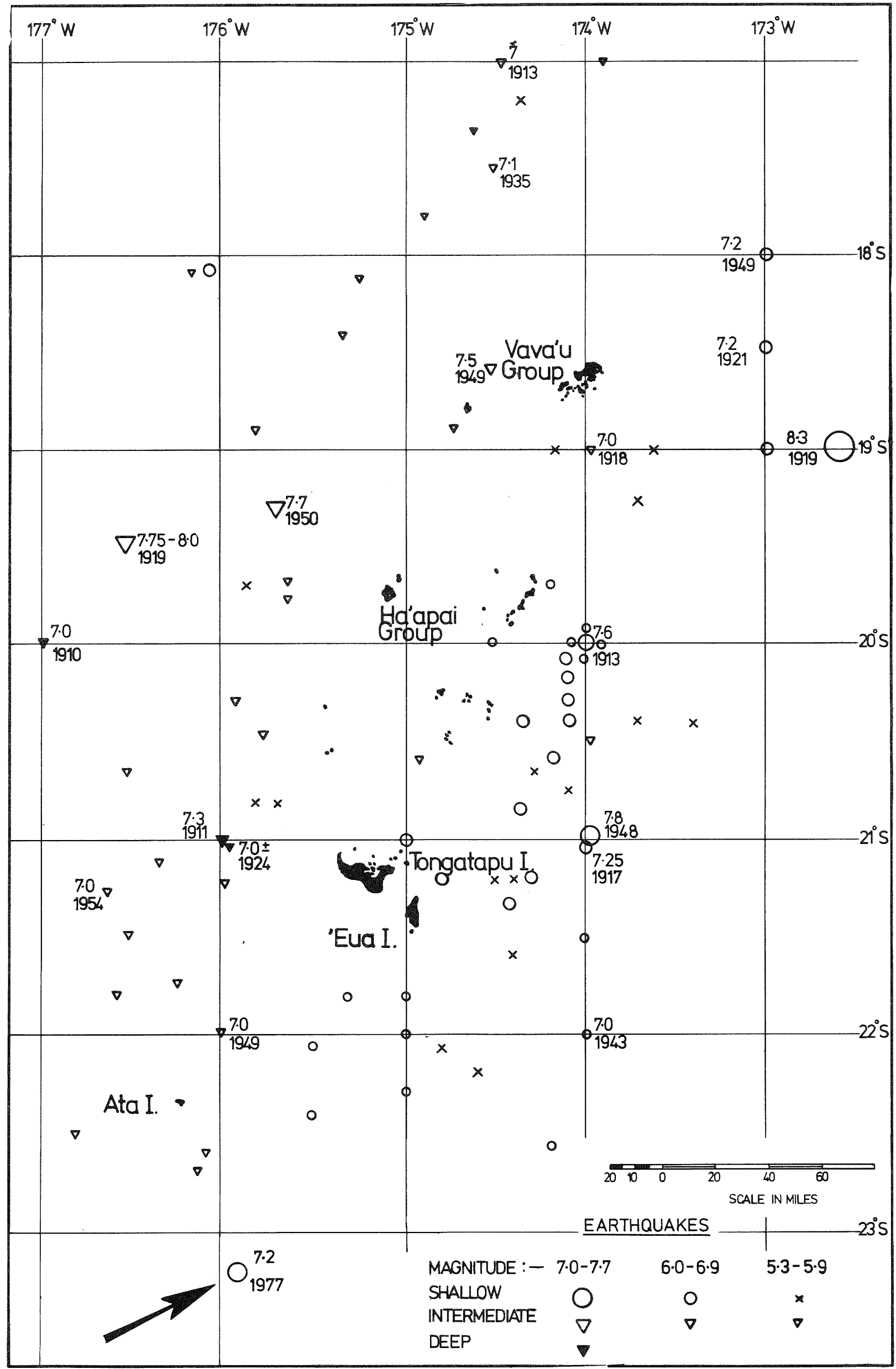

FIGURE 1: LOCATION OF TONGA EARTHOUAKE JUNE, 1977 AND RECORDED EVENTS BEFORE 1965 


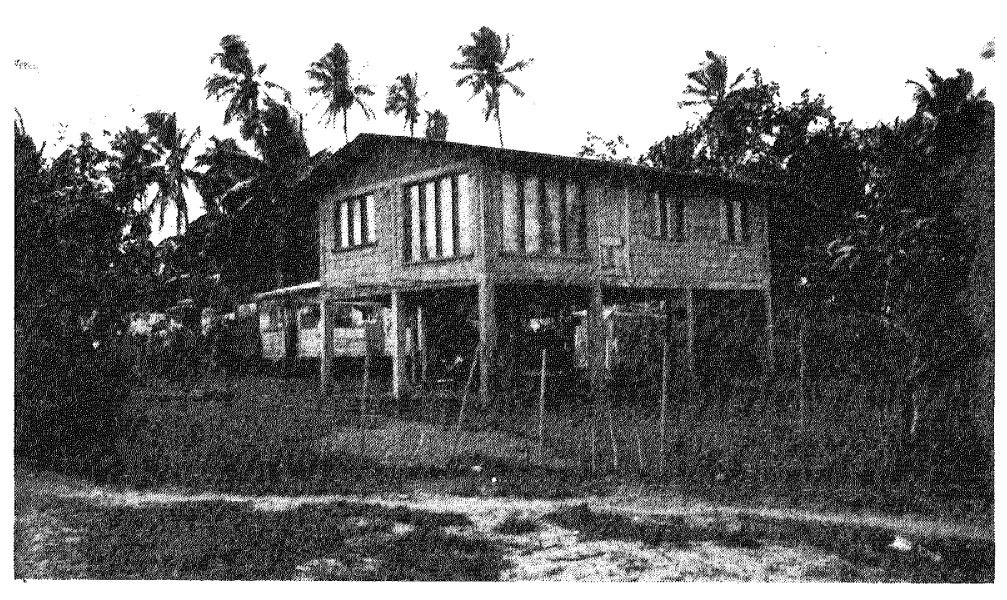

FIGURE 2: HOUSE ON LONG PILES

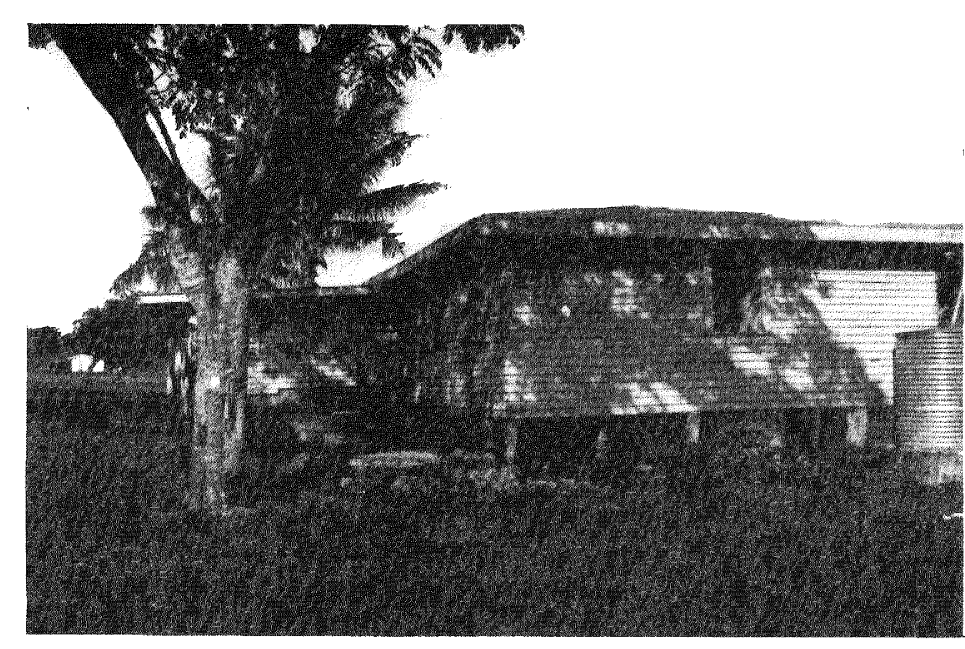

FIGURE 4: TIMBER HOUSE ON PRECAST PILES SAVED BY CONCRETE STEPS

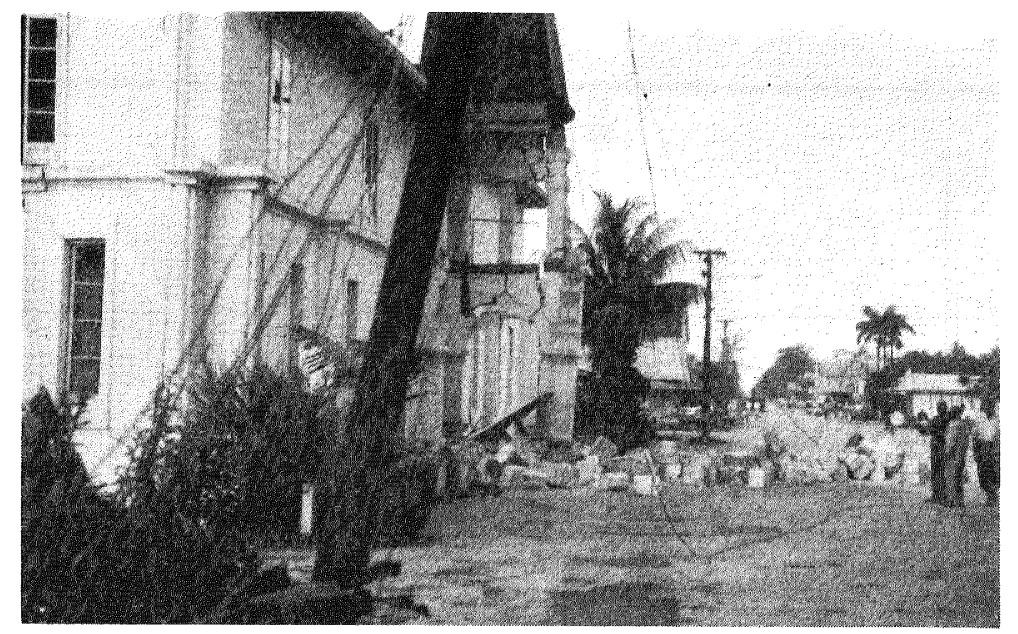

FIGURE 3: PRIME MINISTER'S BUILDING, NUKU'ALOFA. NOTE POWER LINES.

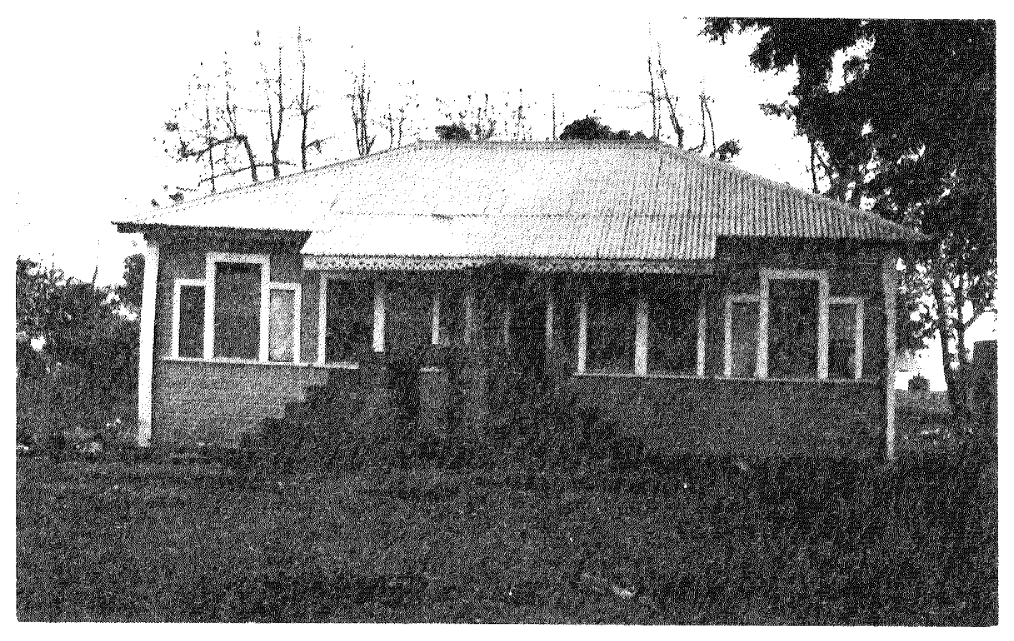

FIGURE 5: TIMBER HOUSE OFF PILES FRONT STEPS NOW REDUNDANT 


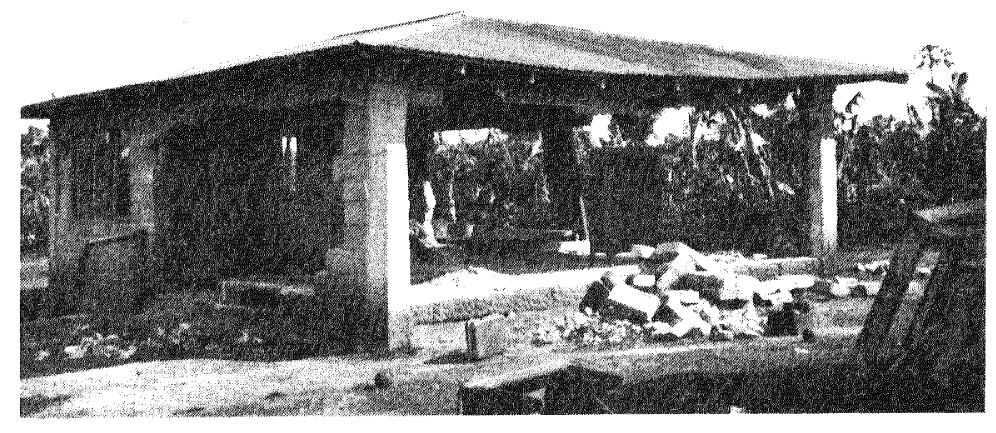

FIGURE 6: MASONRY HOUSE, 'EUA - RC CORNER COLUMNS PREVENTED ROOF COLLAPSE

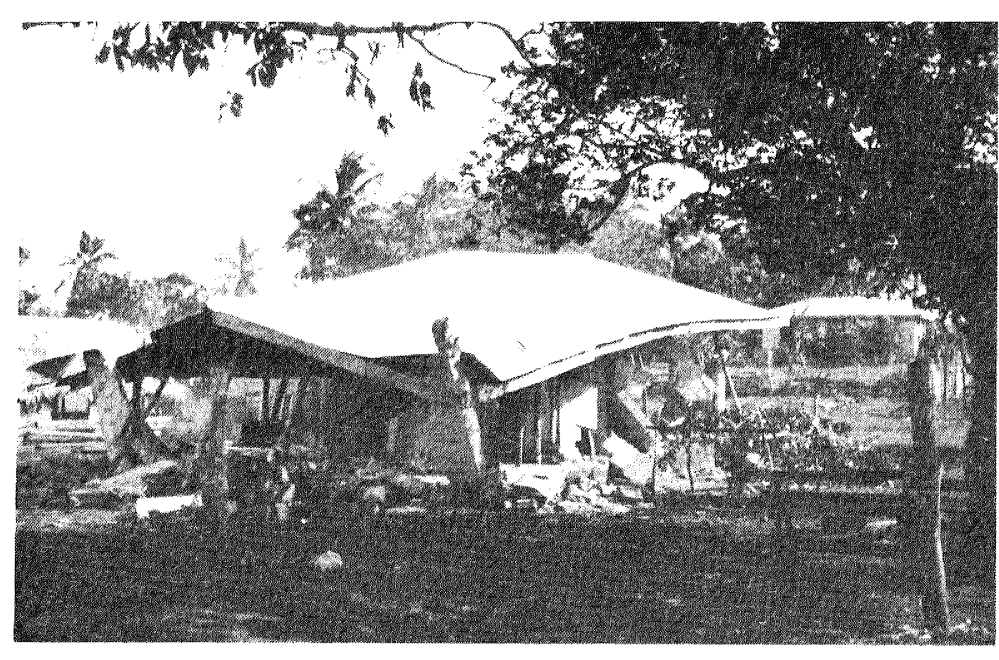

FIGURE 8: MASONRY HOUSE 'EUA - INTERNAL TIMBER PART!TIONS PREVENTED COMPLETE COLLAPSE

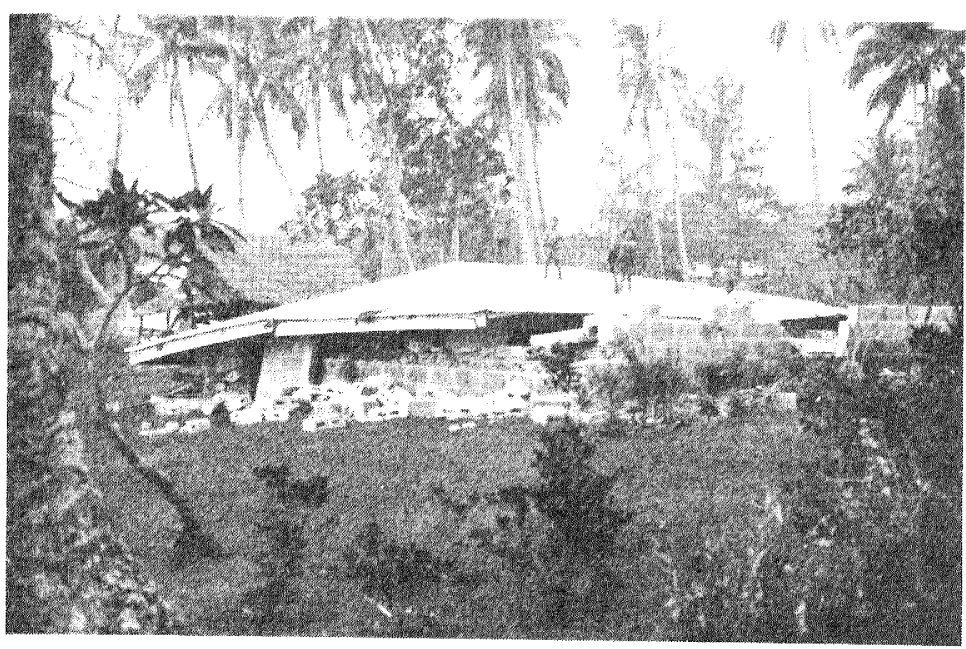

FIGURE 7: COMPLETE COLLAPSE OF MASONRY HOUSE, 'EUA

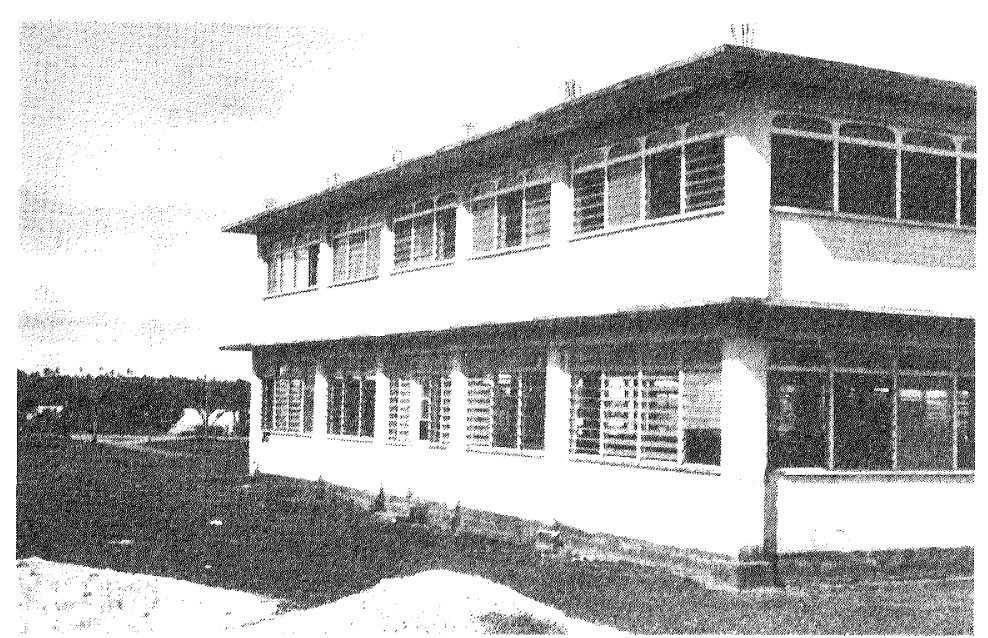

Figure 9: TAILULU COLLEGE, NUKu'Alofa 


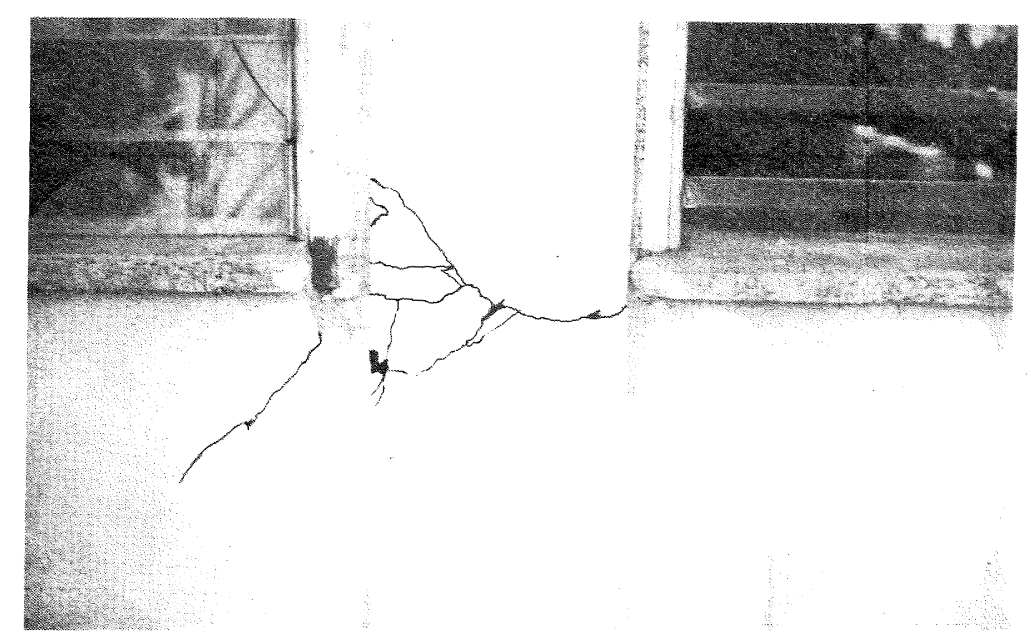

FIGURE 10: EXTERNAL COLUMN AND UNREINFORCED MASONRY INFILL - TAILULU COLLEGE

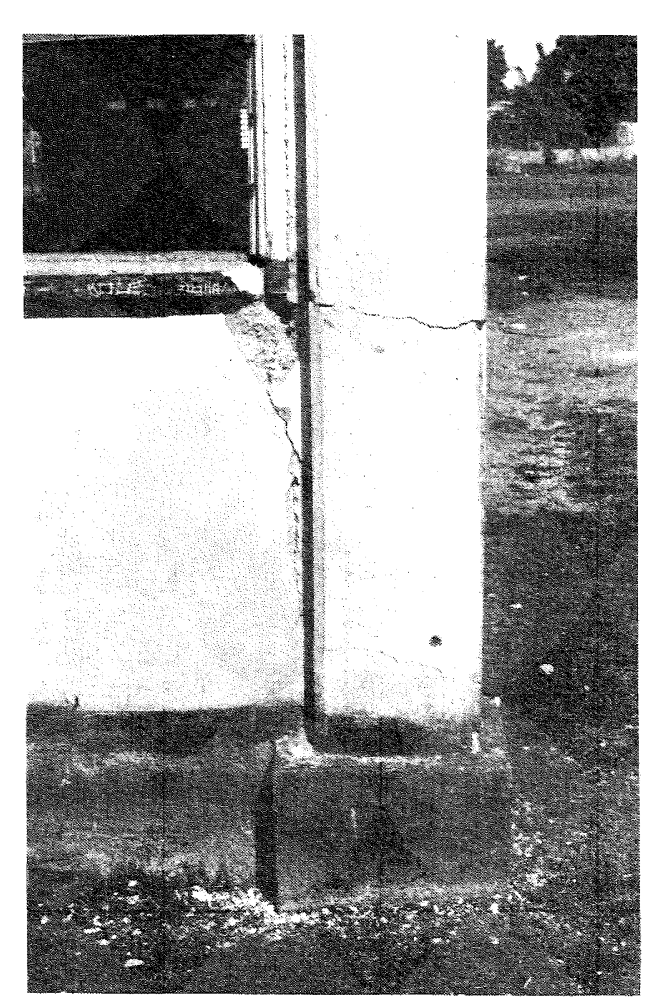

FIGURE 11: CORNER COLUMN SHOWING CRACKING AT BOTTOM AND SILL LEVEL AT TAILULU COLLEGE

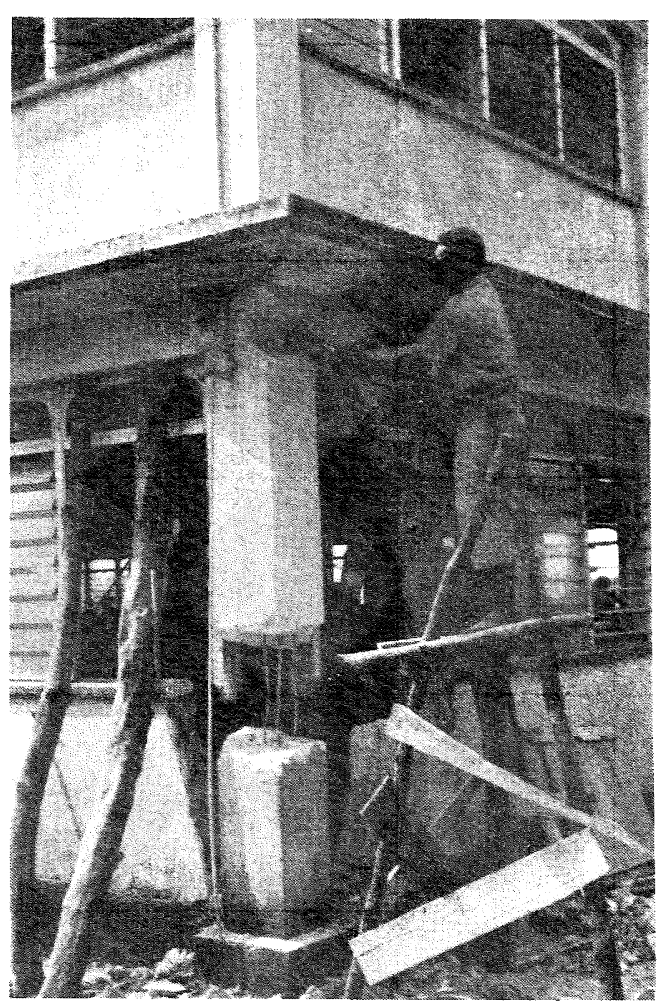

FIGURE 12: CORNER COLUMN UNDER REPAIR TAILULU COLLEGE 


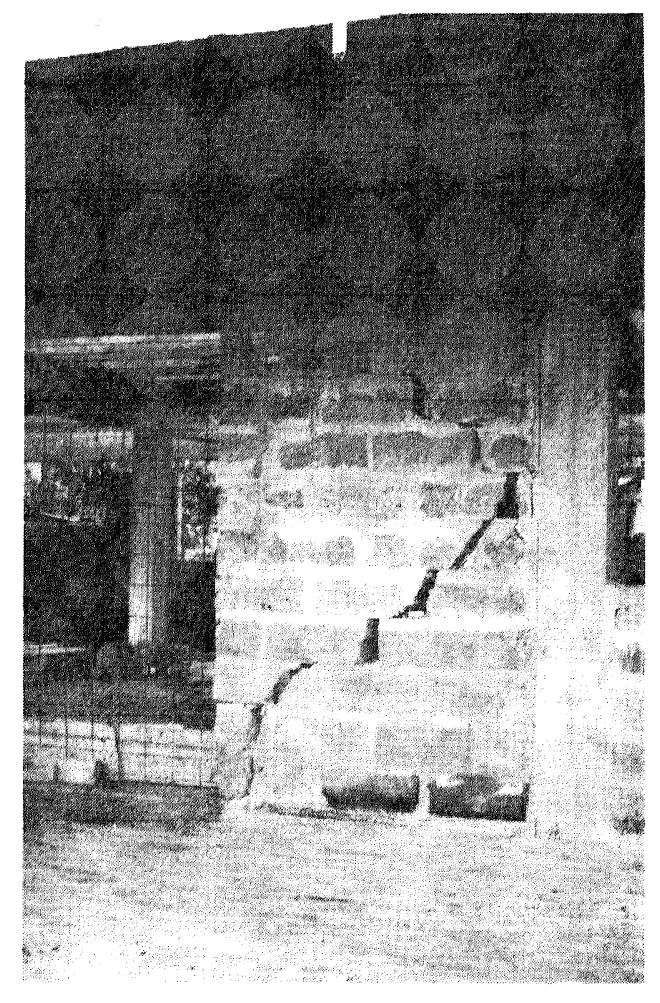

FIGURE 13: UNREINFORCED SHEAR PANEL FAILURE IN UNFINISHED 2 STOREY HOUSE, NUKUNUKU

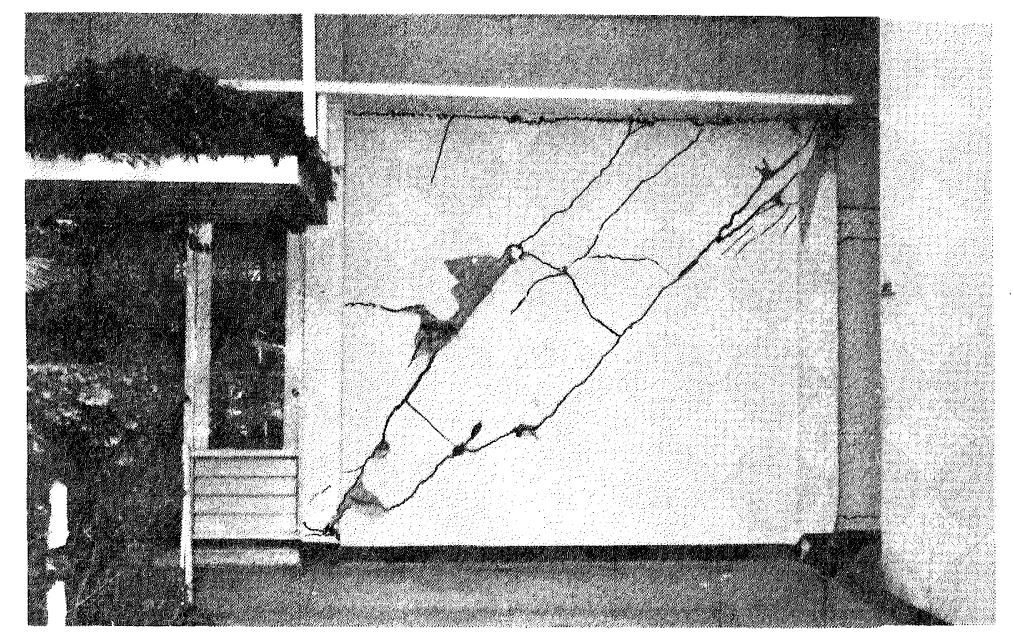

FIGURE 14: INTERNATIONAL DATELINE HOTEL CRACK THROUGH COLUMNS AND MASONRY INFILL PANEL

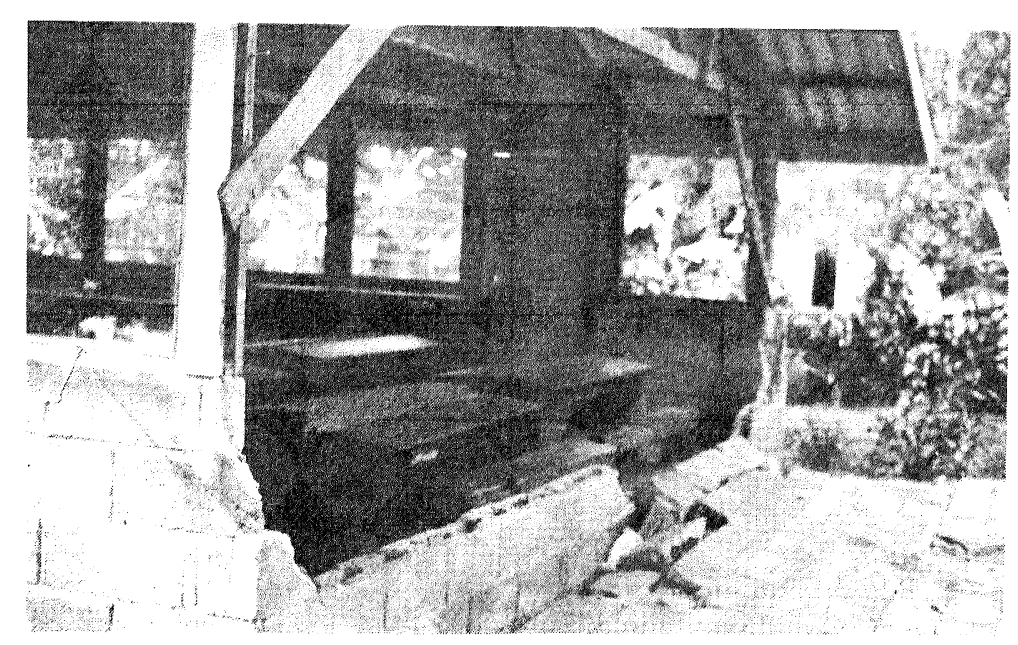

FIGURE 15: COLLAPSED MASONRY END WALL SHOWING LACK OF REINFORCEMENT 


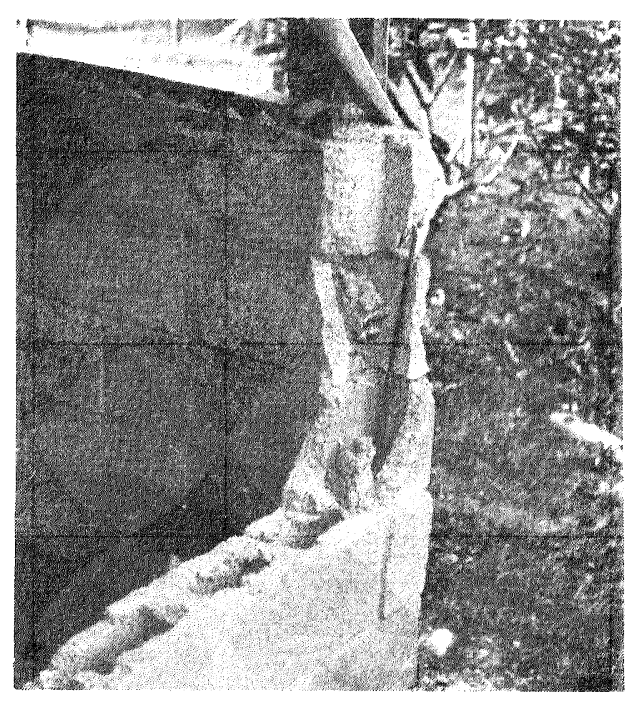

FIGURE 16: CLOSE UP OF WALL IN FIG 14 SHOWING LACK OF GROUT AND REINFORCEMENT

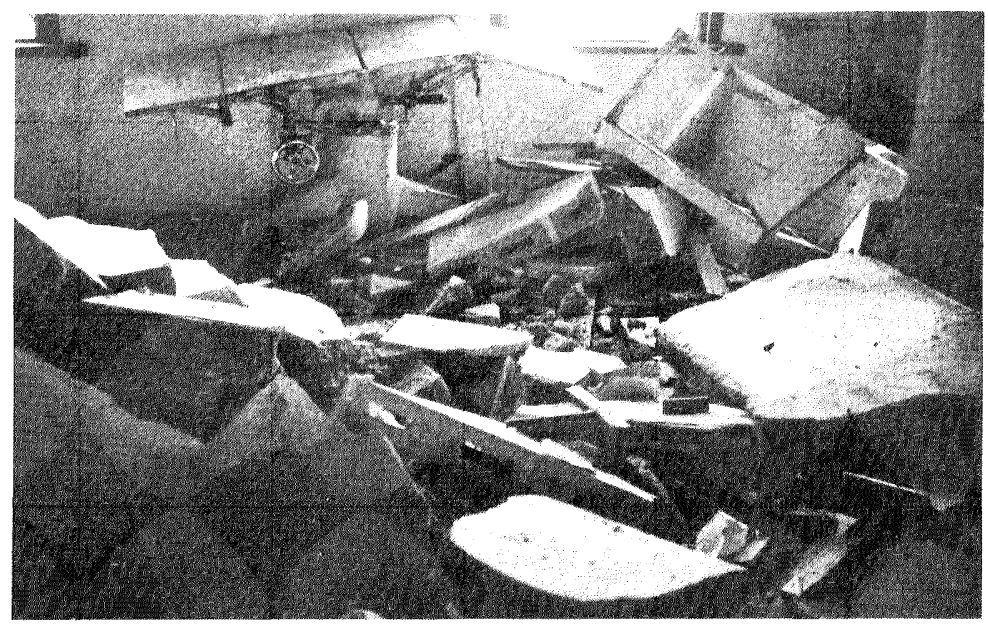

FIGURE 18: COLLAPSED UNREINFORCED MASONRY PARTITIONS 'EUA HOSPITAL

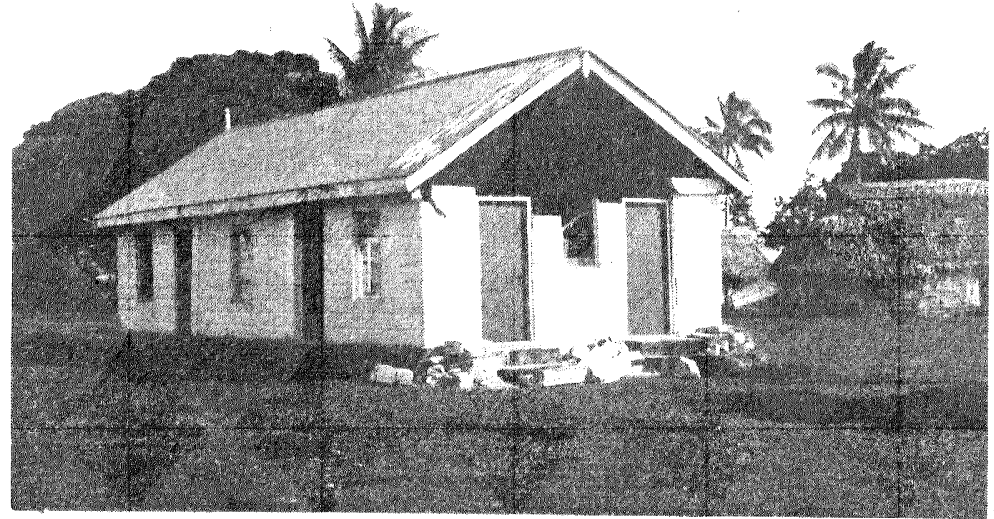

FIGURE 17: TYPICAL FAILURE OF MASONRY GABLE NOTE TRADITIONAL FALE ON RIGHT

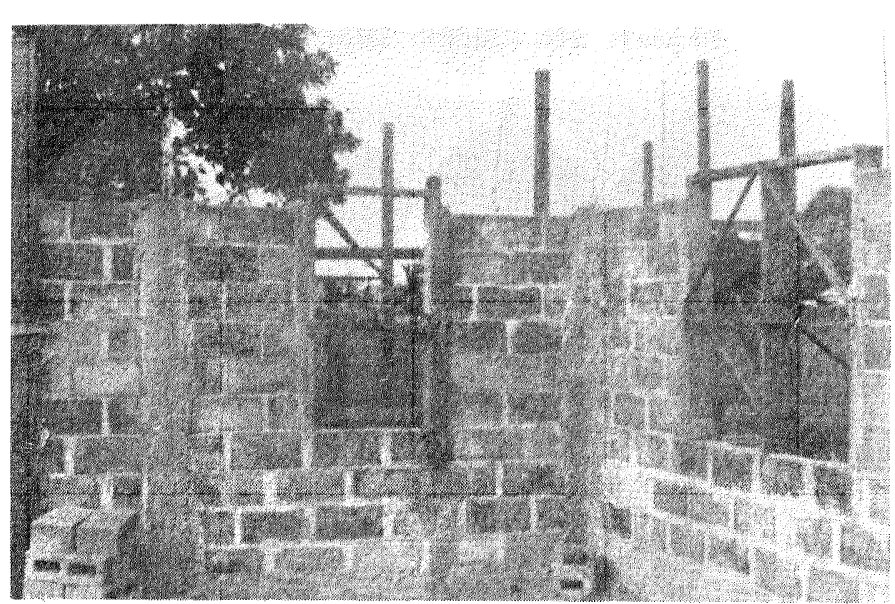

FIGURE 19: HOUSE UNDER CONSTRUCTION AFTER E.Q. 


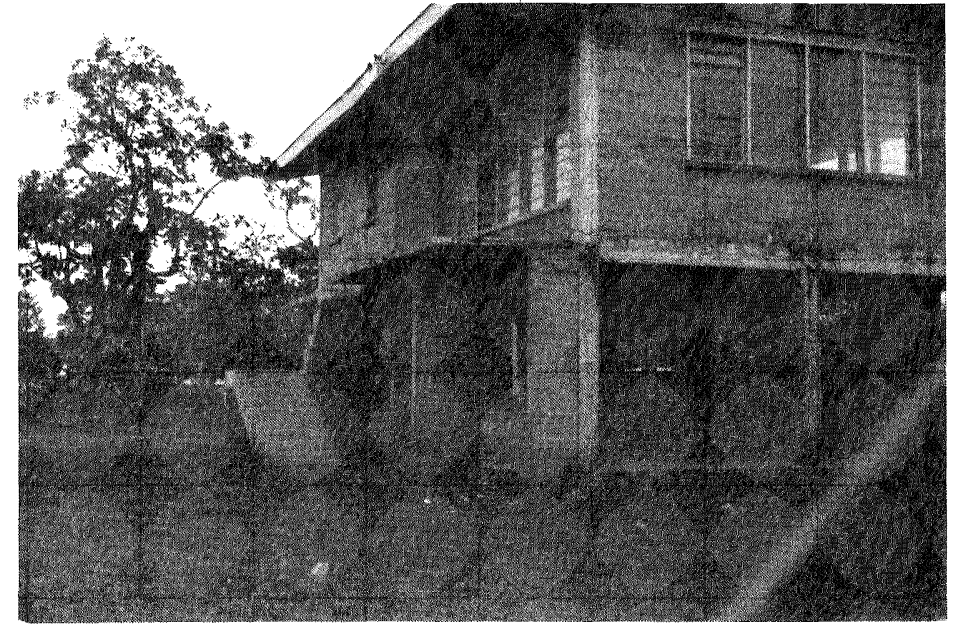

FIGURE 20: HOUSE, NUKUNUKU SHOWING DAMAGE TO STAIRS

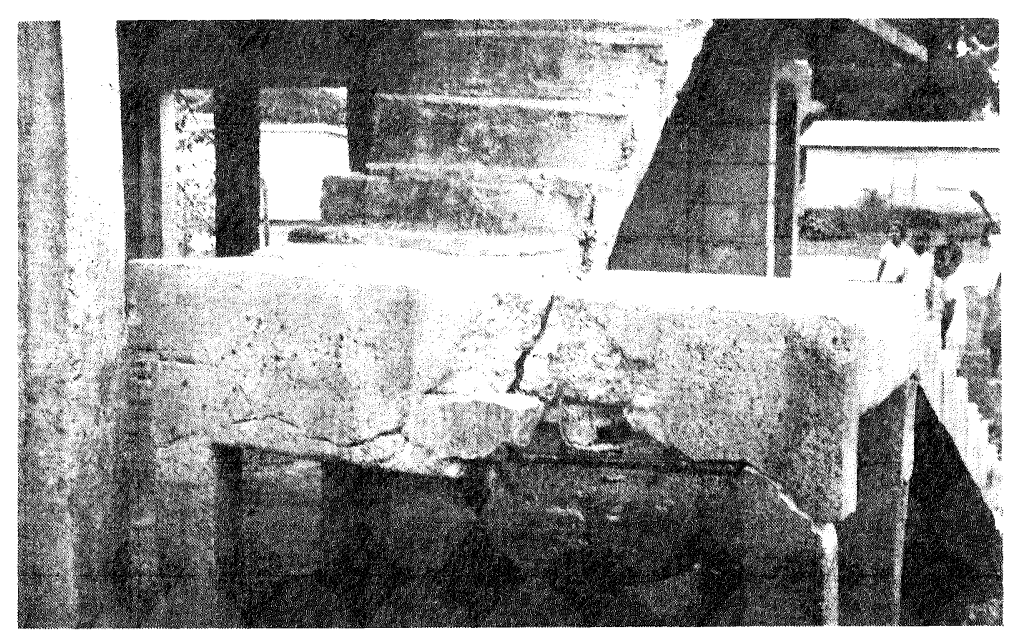

FIGURE 21: CLOSE UP OF STAIRS SHOWN IN FIGURE 20

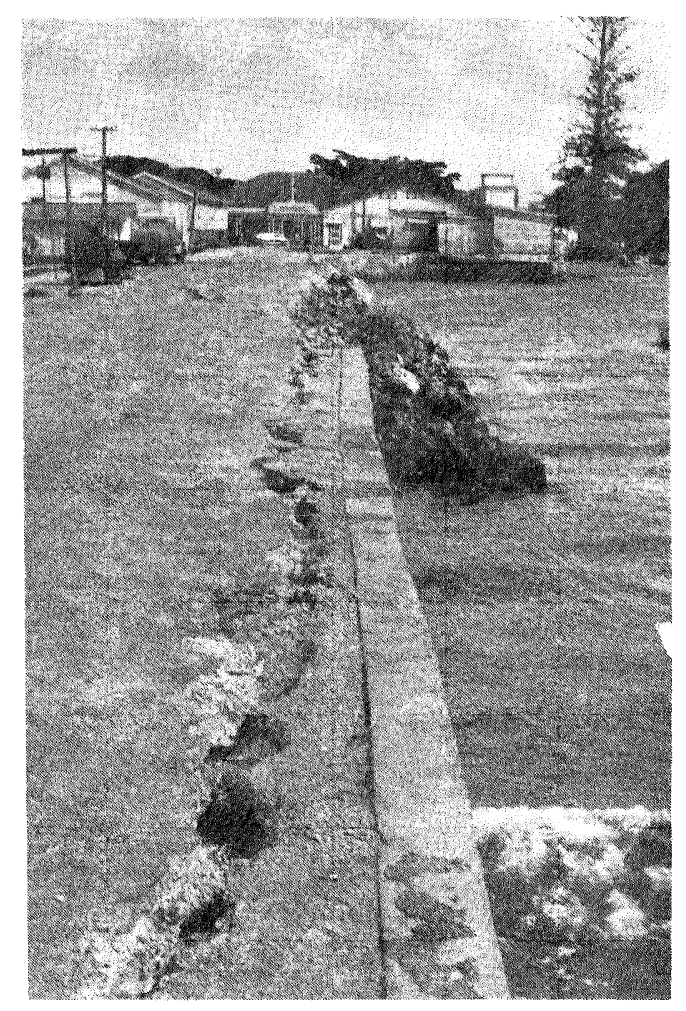

FIGURE 22: VUNA WHARF MOLE, NUKU'ALOFA 


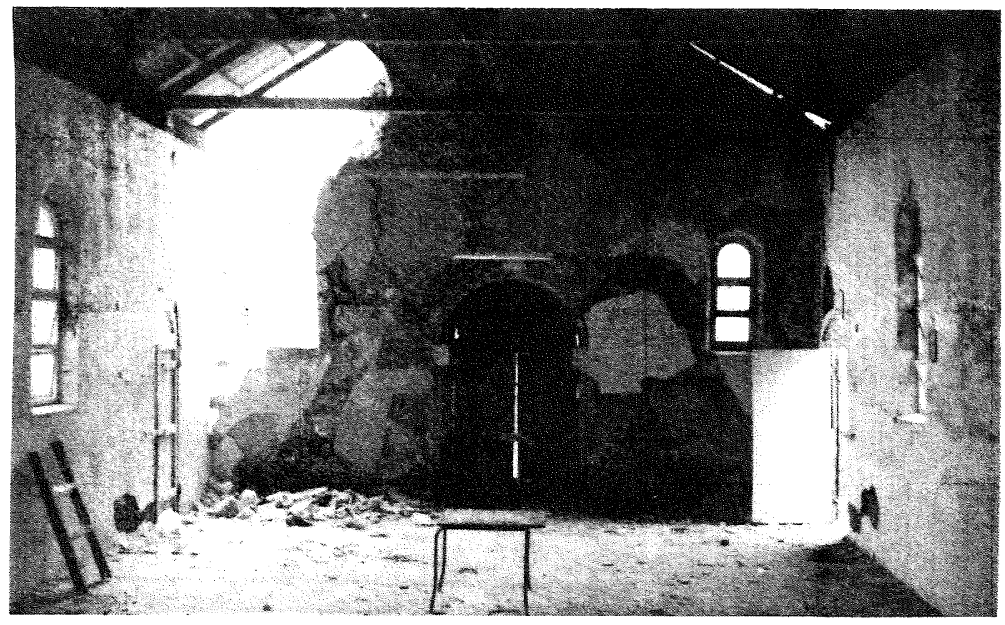

FIGURE 23: END WALL SUPPORTING TOWER ROMAN CATHOLIC CHURCH, KOLOVAI, TONGATAPU. WALLS OF WEAK MASS CORAL CONCRETE

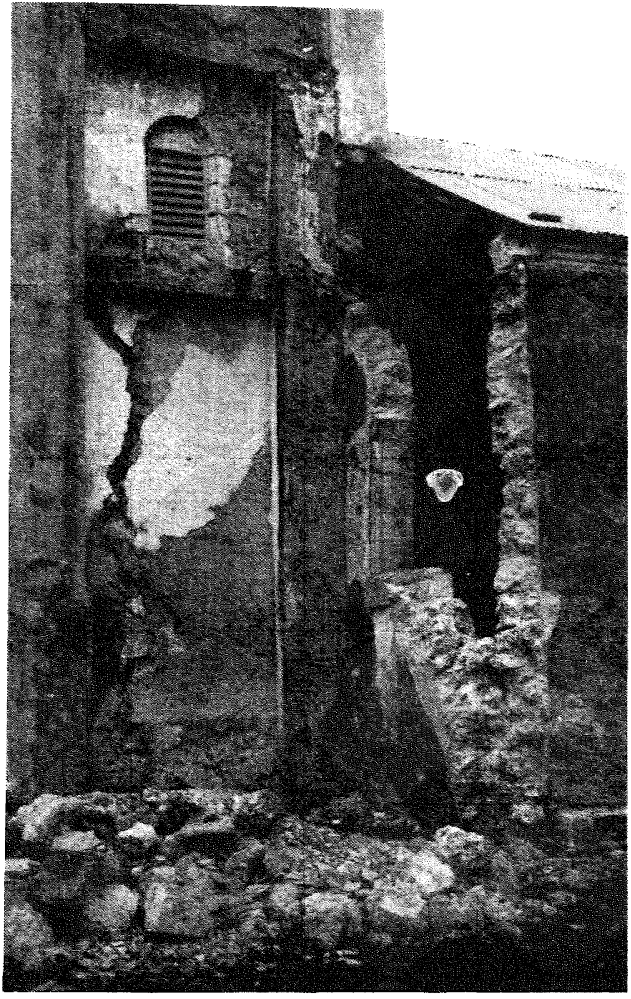

FIGURE 24: WALL COLLAPSE CAUSED BY TOWER MOVING OUT OF PHASE WITH CHURCH, OTHER SIDE NEAR COLLAPSE. SEE FIGURE 23

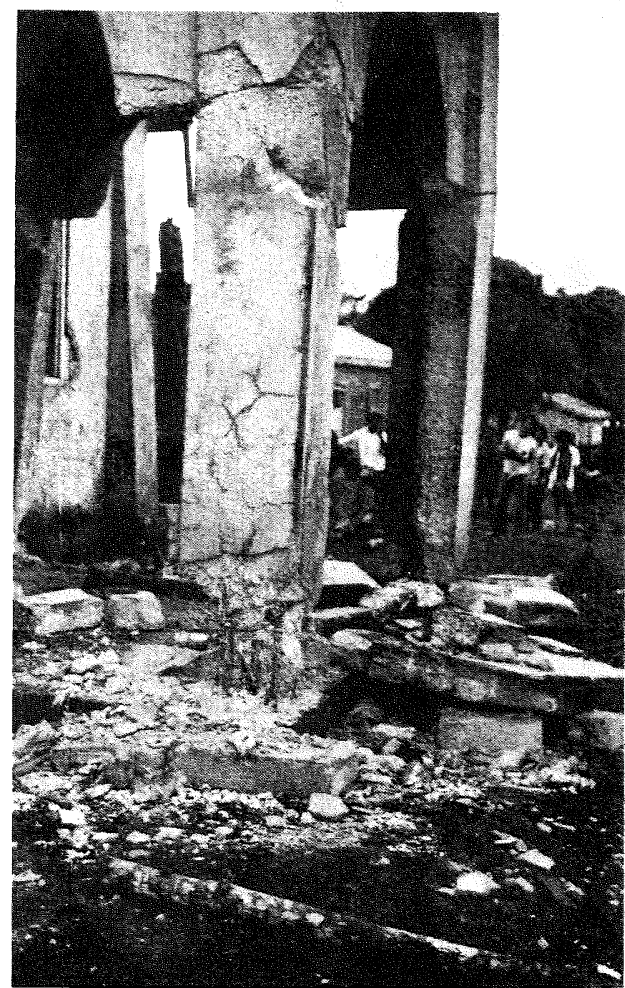

FIGURE 25 :

COLUMNS SUPPORTING TOWER FREE WESLEYAN CHURCH, PETANI, 'EUA 